\title{
Cyclophosphamide Effect on the Epithelial Covering of Rats Fetuse's Tongue. A Morphometric Study
}

\author{
Efectos de la Ciclofosfamida en el Epitelio de Revestimiento \\ de la Lengua de Fetos de Rata. Un Estudio Morfométrico
}

"M. B. I. De Lucia \& ${ }^{* *}$ R. Azoubel

DE LUCIA, M. B. I. \& AZOUBEL, R. Cyclophosphamide effect on the epithelial covering of rats fetuse's tongue. A morphometric study. Int. J. Morphol., 23(2):105-109, 2005.

SUMMARY: The present study has the aim to describe morphologically, morphometrically and stereologically some changes in the tongue epithelium of rat fetuses under the effect of cyclosphosphamide. This drug was used in a single $6 \mathrm{mg} / \mathrm{kg}$ according to the body weight in the tenth - pregnancy day while the control group received equal dosage of saline solution by the same duct and in the same day of pregnancy. The fetuses were plunged into fixed solution of Bouin for five days and the heads of then were divided and blocked in paraffin. Histological sections of six-micrometer thickness were performed and then colored with hematoxilin and eosin. It was used morphometrical and stereological analysis after the morphological study. The data were submitted under the statistical non-parametric test of Mann-Whitney. The results showed that the cyclosposphamide usage effect during the rat pregnancy caused a delayed in the embryo fetal growing, a reduction in the placental weight as wells as in the umbilicus cord length. The covering epithelia in the tongue of the treated group showed some changes since there was an epithelial hyperplasia associated with a cell hypotrophy. The fetuses in this group were more premature than the ones in the control.

KEY WORDS: Cyclophosphamide; Teratology; Tongue.

\section{INTRODUCTION}

Cyclophosphamide, a nitrogen mustard compound is a member of the group of cytostatic alkylating agents. Its actions lead to splitting of the DNA molecule as well as crossed linking of DNA's double helix which interfere with DNA replication and RNA transcription (Goodman \& Gilman, 2003).

Hepatic metabolism of cyclophosphamide by the microsomal P450 mixed function oxidase system forms hydroxycyclophosphamide. This metabolite, or its tautomeric aldehyde, aldophosphamide, split spontaneously to form two other cytostatic compounds, phosphoramide mustard an acrolein (Wingaarden et al., 1997).

Phosphoramide mustard has the DNA as its main target, while acrolein affects proteins. This data as well that of Slott \& Hales (1987), indicates that phosphoramide mustard is toxic to the embryo, and acrolein to the yolk sac.
Most anomalies caused by cyclophosphamide affect the face, and to a significant extent, its middle and inferior third: cleft palate; micrognatia; braquignatia and cleaved lips, (Antoniades et al., 1995; Eriksen et al., 1995) all intrinsically related to the tongue (Antoniades et al.), since the facial anterior growth is likely to reflect the tissue grown between the mandible and the maxillary that is, the tongue and the alveolar process (Eriksen et al.).

Based on the above reported information, and considering that some pregnant women who have to use immunosuppressive drugs for the treatment of diseases like Hodgkin's disease, (Greenberg \& Tanaka, 1964) leukemia (Pizzuto et al., 1980), non-Hodgkin lymphoma (Falkson, et al., 1980), systemic lupus erythematosus (Kirshon et al., 1988) do not always agree to interrupt their pregnancy even when knowing about the risks of such treatment, the present study was aimed at an investigation of the effects of

\footnotetext{
* Doutor in Health Science by Faculdade de Medicina de São José do Rio Preto - São Paulo - Brazil.

*** Full Professor of the Faculdade de Medicina de São José do Rio Preto - São Paulo - Brazil.

This paper is a part of the thesis for obtaining the doctor degree at the Faculdade de Medicina de São José do Rio Preto, Estado de São Paulo - Brazil.
} 
cyclophosphamide on the following aspects of fetal rat development: 1. Induction of malformations; 2. Fetal and placental weight; 3 . Length of the umbilical cord and 4 . The epithelial covering of the tongue.

\section{MATERIAL AND METHOD}

Fourteen female rats (Ratus norvegicus albinos, Wistar) weighing on an average $170 \mathrm{~g}$ were used. Seven animals were given cyclophosphamide and seven served as controls.

A dose of $6 \mathrm{mg} / \mathrm{kg}$-body weight was given intraperitoneally on the $10^{\circ}$ day of pregnancy to the rats of the treated group. Animals of the control group received the same volume of saline by the same route.

Animals were sacrificed on the $20^{\circ}$ day of pregnancy by inhalation of ethyl eter. Following a large incision in the animal's abdomen and uterus, fetuses were exposed and collected. Fetuses, placentas and umbilical cords were fixed in Bouin's solution for 5 days, dried with filter paper and weighed on a Labor balance; lengths of umbilical cords were measured on a millimeter scale. Five fetuses from the treated and control groups respectively, were randomly chosen and separated.

Histology. Heads of fetuses were detached from their bodies at the median level, and dehydrated, diaphanized and included in paraffin. Six-micrometer thick serial histological sections were made, equivalent to a total of 500. Ten sections per block were divided, each of them therefore, equivalent to an interval of fifty sections. The sections werestained in hematoxylin/eosin fluid.

Morphometry. Karyometric: Sala et al., (1992) karyometric parameter were used.

Stereology: Structures studied were drawn on paper according to Merz (1968).

Statistical analysis: Mann-Whitney (Siegel, 1975) nonparameter test was used to analyze the data, employing several software programs created by G. Maia Campos for mathematical calculations in stereological studies.

\section{RESULTS}

In $84,5 \%$ of the fetuses from mothers who had received cyclophosphamide, the following malformations were observed: microcephaly (in 25\%), microphtalmy (in 17\%), hydrocephalus (in 8,5\%) and anophtalmia (in 34\%); several cases of resorption occurred.

Average body weight (1,92 g) of fetuses from the cyclophosphamide-treated group was lower than that of fetuses from the control group $(4,07 \mathrm{~g})$. This difference was shown to be statistically significant by the Mann-Whitney test.

Average placental weight $(279,0 \mathrm{~g})$ of animals of the treated group was significantly lower than that of controls $(472,0)$.

Average length of the umbilical cord of fetuses from the treated group $(1,24 \mathrm{~cm})$ was less than the length of the umbilical cord of fetuses of controls $(1,94 \mathrm{~cm})$. This difference was statistically significant at $\mathrm{a} \leq 0,01$.

Histopathological.Tongue. Control Group. The keratinized epithelium lining in several regions of the fetuses is stratified. Filliform papillae under formation are all in the dorsal anterior surface of the tongue. Fungiform papillae are not well formed. It is easy to observe all over the tongue, a basal layer of low columnar cells with little cytoplasm and a oval basophilic nucleus, whose long axis is perpendicular to the basal membrane. Mitosis is restricted to the basal layer cells.

The granular, kerato-hyaline layer is formed by two or three layers of flattened cells on the spiny layer. It is possible to observe a thin corneal layer of flattened cells and pycnotic nucleoli.

Treated Group. In the anterior region of the dorsal tongue, the epithelium is less thick presenting a greater number of small cells. Papillae are not yet formed; no granular or corner layers are formed.

In the posterior region of the tongue, the epithelium is less thick with a large number of small-sized spiny cells, divided like those of the control group. Delicate fibers and voluminous fibroblasts form a lamina propria.

\section{DISCUSSION}

Tongue development starts in the $4^{\circ}$ intrauterine week in man, and on the $10^{\circ}$ day in the rat, chosen as the day of cyclophosphamide administration in this study. Although the dose chosen is considered to be highly teratogenic, it does not injure the mother except for some loss of weight. (Holladay et al., 2002) The use of this single, high dose was based on results obtained by Lopes et al., (1987) who showed 
it to have a longer-lasting teratogenic effect. According to these authors, smaller doses given at short intervals might lead to repair of cellular lesions, and this is confirmed by Goodman \& Gilman.

The teratogenic mechanism of cyclophosphamide action involves induction of cellular death in cells of rapid proliferation by limitation of DNA synthesis. In interfilamentary cross connections, such as those produced by elevated doses of cyclophosphamide, cause extensive cross connections, causing fragmentation of DNA. (Goodman Gilman; Da Silva et al., 2000) The final cause of cellular death related to DNA lesions is not known. Specific cellular responses include cessation of the cellular cycle, DNA repair and apoptosis. Such responses are pharmacological actions that perturb fundamental mechanisms involved in cellular growth, mitotic activity, differentiation and functioning. This capacity to interfere in normal mitosis and in cellular division in all tissues of rapid proliferation supplies a basis for its therapeutic application and explains much about its toxic properties (Goodman \& Gilman).

Fetuses of mothers who had been given cyclophosphamide presented a significant reduction in body weight, considered to reflect fetal changes and embryotoxicity of the drug. Similar weight reduction had been observed in mice (Vinson \& Hales, 2003).

A delay in fetal growth observed in the present study was initiated in the $10^{\circ}$ day of pregnancy, the day of administration of cyclophosphamide; it could be a sign of cell damage extending into the fetal growing phase. According Moore \& Persaud (1994), biochemical differentiation precedes histological differentiation, an indication that the former is sensitive to interference a few days prior the appearance of visible signs of delayed development.

Placentals of treated rats leading to a reduction of the organ's size, is due to the effect of cyclophosphamide on DNA synthesis (Scott, 1977). Smaller placentas are likely to show a reduced blood flow resulting in some hypoxia to the fetuses, which may contribute to delayed intrauterine growth (Emmanouilides et al., 1972).

The average length of the umbilical cord of fetuses from cyclophosphamide treated mothers was less than those fetuses of control animals. The length of the umbilical cord is related to at least two factors: incidence of fetal moving and available intrauterine area. The reduction of either of these factors decreases the extension of the umbilical cord and might be an index of fetal activity as well as an aid for the diagnosis of certain anomalies. (Moessinger et al., 1982). Reduction of the volume of the amniotic fluid was one of the findings of this work; changes in growth rate in the absence of external malformations can occur. Although the proper amount of amniotic fluid for normal growth of the fetuses is unknown, reduction in its volume has been shown to cause placental growth disturbance consequent to decrease blood flow (Moore \& Persaud).

The epithelial lining of the tongue of fetuses from cyclophosphamide treated mothers presented a lessened thickness, a large numbers of cells, no keratin and a high increase in epithelial cell numerical density. This finding indicates that cellular followed by epithelial hyperplasia occurred in fetuses from pregnant rats receiving cyclophosphamide. Toxic hypotrophy results from the action of substances able to cause the blockade of enzymatic processes leading to reduction of the production of energy as well as the capacity for cells synthesis (Lopes et al.).

According Little \& Mirke (1992) the mechanism of action of mustard phosphoramide is as follows: it first links to DNA, in the $\mathrm{S}$ phase resulting in cross-linking, half of which of DNA to DNA, and half of DNA to proteins. DNA duplication decreases but to a sufficient extent in the G2 phase to the cell cycle. Cell nuclei having cross-linking are incapable of complete mitosis and are blocked for some time at the G2 stage. This explains not only the higher sensitivity of cells to alkylation in late G1 and S phases, but also a lesion expressed by the blockage of division observed in the G2 phase. (Goodman \& Gilman; Wingaarden et al.). Cells accumulating prior to blockage at G2 may present a double DNA complement. At the same time they would continue to synthesize other cell components like proteins and RNA. This could lead to a lack of balanced growth, leading to larger cells or increased cell numbers. (Goodman \& Gilman). Our findings suggest that this mechanism could explain why lingual ephitelia of fetuses from treated mothers show a great number of cells or hyperplasia. This may be related to the fact that in the $\mathrm{G} 2$ phase there occurs a great amount of cyclophosphamide linked to the cell nucleus, since in this phase the nucleus presents greater duplication of DNA in comparison to the G1 phase. (Goodman \& Gilman; Little \& Mirkes).

Apoptosis is the aim of teratogenicity of the cyclophosphamide (Chen et al., 1994; Mirkes \& Lithle, 1998). Thus immaturity shown by treated fetuses in the present work could be explained by alterations of the cellular cycle as well as by blockage of mitosis and increase apoptosis. This conclusion is reinforced by the hypothesis of Bursch et al. (1992) and Torchinsky et al., stating that when apoptosis is disturbed by inhibited or inadequate induction, malformations certainly occur. 
Microglossia found in fetuses of the treated group is not a common condition and according to Moore \& Persaud might be associated with micrognathia and limb malformations. Micrognathia was also found in animals treated with cyclophosphamide (Torchinsky et al.).
Genic and chromosomal mutations are associated with nearly $14 \%$ of malformations (Plavcan \& German, 1995). Since cyclophosphamide evidently is mutagenic, the data of the present work reinforce the dilemma of treating pregnant women with this drug. Considering the risklbenefit issue, we state that this drug should not be used during the first trimester of pregnancy.

DE LUCIA, M. B. I. \& AZOUBEL, R. Efectos de la ciclofosfamida en el epitelio de revestimiento de la lengua de fetos de rata. Un estudio morfométrico. Int. J. Morphol., 23(2):105-109, 2005.

RESUMEN: El estudio tiene como objetivo describir morfológica, morfométrica y estereológicamente algunos cambios en el epitelio de la lengua de fetos de rata bajo los efectos de la ciclofosfamida. Esta droga fue usada en una muestra única de $6 \mathrm{mg} / \mathrm{kg}$ de acuerdo al peso del cuerpo, en el décimo día de preñez, mientras el grupo control recibió igual dosis de una solución salina, por la misma vía, en los mismos días de preñez. Los fetos fueron sumergidos en solución fijadora de Bouin, por cinco días y las cabezas de ellos fueron cortadas y colocadas en bloques de parafina. Secciones histológicas de $6 \mu \mathrm{m}$ fueron teñidas con hematoxilina-eosina. Después del estudio morfológico se realizaron análisis morfométricos y estereológicos. Se utilizó el test estadístico no paramétrico de Mann-Whitney. Los resultados mostraron que el uso de la ciclofosfamida provoca efectos durante la preñez de la rata, causando un retardo en el crecimiento de los embriones, una reducción en el peso de las placentas como también, en la longitud del funículo umbilical. El epitelio de revestimiento de la lengua del grupo tratado, mostró algunos cambios desde una hiperplasia epitelial asociada con una hipotrofia celular. Los fetos del grupo tratado fueron más prematuros que los del grupo control.

PALABRAS CLAVE: Ciclofosfamida; Teratología; Lengua.

\section{REFERENCES}

Antoniades, K.; Economou, L.; Sioga, A.; Vahtsevanos, K. \& Manthos, A. Patogénesis of bromodeoxyuridineinduced cleft palate in mice. J. C. Maxillofacial Surgery, 23:(4)203-70, 1995.

Bursch, W.; Oberhammer, F. \& Schulte-Hermann, R. Cell death by apoptosis and its protective role against disease. Trends Pharmacol. Sci., 13:245-51, 1992.

Chen, B.; Cyr, D.G. \& Hales, B.F. Role of apoptosis is mediating phosphoramide mustard-induced rat embryo malformations in vitro. Teratology, 50:1-12, 1994.

Da Silva, I. U.; McHugh, P. J.; Clingen, P. H. \& Hartley, J. A. Defining the roles of nucleotide excision repair of DNA interstrand cross-links in mammalian cells. Mol. Cell Biol., 20:7980-90, 2000.

Emmanouilides, C. G.; Hobel, C. J.; Yashiro, K. \& Klyman, G. Fetal responses to maternal exercise in the sheep. Amer. J. Obstet. Gynecol., 112:130-7, 1972.

Eriksen, E.; Bach-Petersen, S.; Eynde, B.; Solow, B. \& Kjaer, I. Midsagital dimensions of the prenatal human cranium. J. Craniofac. Genet. Dev. Biol., 15:44-50, 1995.
Falkson, H. C.; Simson, I. W. \& Falkson, G. Non-Hodgkin's lymphoma in pregnancy. Cancer, 45:1679-82, 1980.

Goodman, L. S. \& Gilman, A. As bases farmacológicas de terapêutica. 10. ed., São Paulo, McGraw-Hill, 2003.

Greenberg, L. H. \& Tanaka, K. R. Congenital anomalies probably induced by cyclophosphamide. J. Am. Med. Assoc., 188:423-6, 1964.

Holladay, S. D.; Sharova, L. V.; Punareewattana, K.; Hrubec, T. C.; Gogal Jr, R. M. Prater, M.R.; et al. Maternal immune stimulation in mice decreases fetal malformations caused by teratogens. Inf. Imunol., 2:32532, 2002.

Kirshon, B.; Wasserstrum, N.; Willis, R.; Herman, G.E. \& Mccabe, E. R. B. Teratogenic efects of first trimester cyclophosphamide therapy. Obstet. Gynecol., 72:462, 1988.

Little, S. A.; Mirkes, P. E. Effects of 4- hidroxycyclophosphamide (4-OOH-CP) and 4-hydroperoxydechlorocyclophosphamide (4-OOH-deCICP) on the cell cycle of postimplatation rat embryos. Teratology, 45:163-73, 1992. 
Lopes, E. R.; Chapadeiro, E.; Raso, P. \& Tafuri, W. L. Bogliolo Patologia. 4. ed. Rio de Janeiro, Guanabara Koogan, 1987.

Merz, W. A. Die Strckenmessung na gerichteten Strukturen im Mikroskop und ihre Anwendung zur Bestmmung von Oberflächen - Columen-Relationen in Knochengewehe. Mikroskopie, 22(5-6):132-42, 1968.

Mirkes, P. E.; Lithle, S. A. Teratogen-induced cell death in post implantation mouse embryos: Differential tissue sensivity and hallmarks of apoptosis. Teratology, 5:592600, 1998.

Moessinger, A. C.; Blanc, W. A.; Marone, P. A. \& Polsen, D.C. Umbilical cord lenght as an index of fetal activity: Experimental study and clinical implications. Pediat. Res., 16:109-12, 1982.

Moore, K. L. \& Persaud, T.V.N. Embriologia Clínica. 5. ed. Rio de Janeiro, Guanabara Koogan, 1994.

Pizzuto, J.; Aviles, A.; Noriega, L.; Niz, J.; Morales, M. \& Romero, F. Treatment of acute leukemia during pregnancy: presentation of nine cases. Cancer Treat Rep., 64:679-83, 1980.

Plavcan, J. M. \& German, R. Z. Quantitative evaluation of craniofacial growth in the third trimester human. Cleft Palate Craniofac J., 32(5):394-404, 1995.

Sala, M. A.; Lopes, R. A. \&Matheus, M. Método morfológico para análisis cuantitativo de los tejidos. Determinación de los parámetros normales para el hepatocito de rata. Arch. Fac. Med. Zaragoza, 32:29-51, 1992.

Scott, J. R. Fetal growth retardation associated with maternal administration of immunosuppressive drugs. Am. J. Obst. Gynecol., 128:668-76, 1977.
Slott, V. L. \& Hales, B. F. Enchancement of the embryotoxicity of acrolein, but not phosphoramide mustard, by glutathione depletion in rat embryo in vitro. Biochem. Pharmacol., 36:2019-25, 1987.

Siegel, S. A. Estatística não paramétrica para as ciências do comportamento. São Paulo, Mc Graw-Hill, 1975.

Torchinsky, A.; Ivnitsky, I.; Savion, S.; Shepshelovich, J.; Gorivodsky, M.; Toder, V. Cellular events and pattern of p53 protein expression following cyclophosphamideinitiated cell death in various organs of develping embryo. Teratog. Carcinog. Mutagen, 19:353-67, 1999.

Vinson, R. K. \& Hales, B. F. Genetoxic stress response gene expression in the mid-organogenesis rat conceptus. Toxicological Sciences, 74:157-64, 2003.

Wingaarden, J. B.; Smith, L .H. \& Bennett, J. C .C. Tratado de Medicina Interna. 20. ed. Rio de Janeiro, Guanabara Koogan, 1997.

Correspondence to:

Dr. M. B. I. De Lucia

Faculdade de Medicina de São Jose do Rio Preto

Pós-Graduação

Av. Brigadeiro Faria Lima, 5416

CEP: $15090-000$

Universitário - São José do Rio Preto - SP

BRASIL

Telefone: (17) 3201-5712

E-mail: mariangela.borghi@terra.com.6r

Recibido : 02-11-2004

Aceptado: 03-03-2005 